\title{
EVALUATION OF THE AMERICAN WATERWEED (ELODEA CANADENSIS MICHX.) AS SUPPLEMENTAL FOOD FOR THE NOBLE CRAYFISH, ASTACUS ASTACUS
}

\author{
E. D'AGARO (1), B. RENAI (2), F. GHERARDI (2)
}

(1) Dipartimento di Scienze della Produzione Animale, Università di Udine, Via S. Mauro 2 33010 Pagnacco (UD), Italy.

(2) Dipartimento di Biologia e Genetica "Leo Pardi", Università di Firenze, Via Romana 17 50125 Firenze, Italy.

Reçu le 6 janvier 2004

Accepté le 5 juillet 2004

Received January 6, 2004

Accepted July 5, 2004

\begin{abstract}
We conducted a preliminary study to evaluate the capacity of summerling Astacus astacus to consume the American waterweed (Elodea canadensis Michx.) under artificial rearing conditions. Summerling $A$. astacus (initial b.w.: $0.32 \pm 0.02 \mathrm{~g}$ ) were cultured $\left(50\right.$ crayfish $\left./ \mathrm{m}^{2}\right)$ in 600 lanks for 89 days. The experimental design was composed of three treatments as follows: control diet (D) (crude protein: $40.9 \% \mathrm{DM}$; ether extract: 7.4\% DM), elodea (E) (crude protein: 25.8\% DM; ether extract: 1.4\% DM) and control diet + elodea $(D+E)$ with three replicates per treatment. Temperature, dissolved oxygen, and other water parameters were measured weekly $\left(\mathrm{T}: 20.1^{\circ} \mathrm{C} ; \mathrm{O}_{2}: 7.2 \mathrm{mg} / \mathrm{l} ; \mathrm{pH}: 7.5\right.$; $\left.\mathrm{N}-\mathrm{NH}_{4}: 0.05 \mathrm{mg} / \mathrm{l} ; \mathrm{N}_{2} \mathrm{NO}_{2}: 0.01 \mathrm{mg} / \mathrm{l} ; \mathrm{N}-\mathrm{NO}_{3}: 29.9 \mathrm{mg} / \mathrm{l}\right)$. The relative growth rate was significantly $(P<0.01)$ higher in treatment $D+E(195 \%)$ and $D(143 \%)$ than in $E(65 \%)$. The reduced growth observed in crayfish fed elodea only can probably be due to the lower dietary lipid level of the plant respect to the standard crayfish requirements. At the end of the experiment, the survival rate of $A$. astacus was higher $(\mathrm{P}<0.05)$ for the treatment $D+E(87 \%)$ and $D(81 \%)$, compared to $E(56 \%)$. Our results suggest that $E$. canadensis can be used as a non-expensive supplemental food in order to increase growth and survival in summerling noble crayfish. They also showed that $A$. astacus has the potential to consume this macrophyte in nature.
\end{abstract}

Key-words: Astacus astacus, nutrition, Elodea canadensis.

\section{ÉVALUATION DE LA PLANTE AQUATIQUE AMÉRICAINE (ELODEA CANADENSIS MICHX.) EN TANT QUE SUPPLÉMENT ALIMENTAIRE POUR LES ÉCREVISSES NOBLES, ASTACUS ASTACUS}

\section{RÉSUMÉ}

Nous avons conduit une étude préliminaire pour évaluer la capacité d'Astacus astacus estivales à consommer l'élodée américaine (Elodea canadensis Michx.) en conditions d'élevage artificiel. Les $A$. astacus estivales (poids initial : 0,32 $\pm 0,02 \mathrm{~g}$ ) ont été élevées (50 écrevisses $/ \mathrm{m}^{2}$ ) dans un aquarium $600 \times 89$. Le dispositif expérimental était composé de trois étapes successives comme suit : régime contrôlé (D) (protéine brute : 40,9 \% DM ; extrait d'éther : 7,4 \% DM), élodée (E) (protéine brute : 25,8 \% DM ; 
extrait d'éther : 1,4\% DM) et un régime contrôlé + élodée $(D+E)$ avec trois réplicats par traitement. La température, l'oxygène dissous, et les autres paramètres de l'eau ont été mesurés hebdomadairement $\left(\mathrm{T}: 20,1{ }^{\circ} \mathrm{C} ; \mathrm{O}_{2}: 7,2 \mathrm{mg} / \mathrm{l} ; \mathrm{pH}: 7,5 ; \mathrm{N}-\mathrm{NH}_{4}: 0,05 \mathrm{mg} / \mathrm{l}\right.$; $\left.\mathrm{N}-\mathrm{NO}_{2}: 0,01 \mathrm{mg} / \mathrm{l} ; \mathrm{N}-\mathrm{NO}_{3}: 29,9 \mathrm{mg} / \mathrm{l}\right)$. Le taux de croissance relatif était significativement $(P<0,01)$ supérieur en $D+E(195 \%)$ et dans le régime contrôlé $D(143 \%)$ qu'en $E(65 \%)$. La croissance réduite observée chez les écrevisses alimentées exclusivement par des élodées peut être due uniquement au régime pauvre en lipides par rapport au standard requis par les écrevisses. A la fin de l'expérience, le taux de survie d'A. astacus est supérieur $(P<0,05)$ pour le traitement $D+E(87 \%)$ comparé à $D(81 \%)$ et $E(56 \%)$. Nos résultats suggèrent que $E$. canadensis peut être utilisée comme supplément alimentaire pour accroître la croissance et la survie des écrevisses nobles estivales. Ils montrent aussi que $A$. astacus a le potentiel de consommer ce macrophyte dans la nature.

Mots-clés : Astacus astacus, nutrition, Elodea canadensis.

\section{INTRODUCTION}

Elodea canadensis, also known as American waterweed, Canadian waterweed, common elodea, or anacharis, is an attractive aquarium plant. Due to its availability in the aquarium trade, it has been introduced from the native North America to several countries (in: Europe, Australia, Africa, Asia, and New Zealand), where it is now considered a noxious weed. It first appeared in Europe in 1836, and then spread rapidly (SCHULTHORPE, 1967; HUTCHINSON, 1975).

Small shoots are sufficient for colonisation and, once established, plants may form dense stands becoming dominant in shallow waters. The species inhabits eutrophic lakes and ponds and also grows in slow moving water in rivers, canals and streams with water temperature ranging between $10-25^{\circ} \mathrm{C}$.

As far as the effects of this species on animal communities are concerned, on one hand, dense populations of these plants strongly influence water physico-chemical parameters, inducing strong diurnal shifts in oxygen concentration and $\mathrm{pH}$ (EUGELINK, 1998) following the patterns of primary production as well as severe oxygen depletion or even anoxia during senescence and dieback (cf. BUSCHEMI, 1958). These changes in the habitat could explain the high mortality of Astacus astacus and Pacifastacus leniusculus occasionally observed in, e.g., eutrophic ponds in Sweden, in relation to the rapid growth of the waterweed (NYSTRÖM, 2002).

On the other hand, Elodea stands could provide good habitats for many aquatic invertebrates and cover for young fish and amphibians. As an example, HORPPILA et al. (2000) observed in a Finnish lake a high consumption of macrophytes, including E. canadensis, by the omnivorous cyprinid roach Rutilus rutilus.

Crayfish are commonly reported to efficiently consume benthic macrophytes (see, e.g., MOMOT et al., 1978, and LODGE and LORMAN, 1987) and, as a consequence, to regulate the density of potentially invasive species. Enclosure-exclosure experiments conducted in North America showed that crayfish species, like Orconectes rusticus, can even suppress Elodea (LODGE et al., 1994). Similarly, ABRAHAMSSON (1966) reported that noble crayfish are able to graze macrophytes in natural lakes of Sweden, therefore reducing by a great extent the E. canadensis surface cover. In contrast, NYSTRÖM's (1999) studies showed that native European species have a generally lower impact on macrophytes than North American species. A reduction in grazing activity of $A$. astacus was observed in the biomass of Chara, but not of Elodea species (NYSTRÖM, 2002). However, adult noble crayfish grazing rate of Elodea has been estimated by HESSEN and SKURDAL (1987) to be $0.2 \mathrm{~g}$ dry wt ind ${ }^{-1} \mathrm{~d}^{-1}$. 
The main objective of the present study was to evaluate the nutritional value of E. canadensis alone or in combination with an experimental diet on growth performance and survival of summerling $A$. astacus reared in a recirculating system.

\section{MATERIAL AND METHODS}

The growth trial was performed in the aquaria at the Department of Animal Production Science (Udine, Italy). Summerling A. astacus were bought in Germany (Augsburg) at the First Bavarian Crayfish Hatchery. Four hundred and fifty individuals (initial live weight: $0.32 \pm 0.02 \mathrm{~g}$ ) were randomly allotted in 9 tanks $\left(1 \mathrm{~m}^{2} \times 0.6 \mathrm{~m}\right)$. The experimental design was composed of three treatments as follows: control diet (D) (crude protein: $40.9 \%$ DM; ether extract: $7.4 \%$ DM), elodea (E) (crude protein: 25.8\% DM; ether extract: $1.4 \% \mathrm{DM})$ and control diet + elodea $(\mathrm{D}+\mathrm{E})$ with three replicates per treatment. Crayfish were fed ad libitum for 89 days. Temperature, dissolved oxygen, and other water parameters were measured weekly $\left(\mathrm{T}: 20.1^{\circ} \mathrm{C} ; \mathrm{O}_{2}: 7.2 \mathrm{mg} / \mathrm{l} ; \mathrm{pH}: 7.5 ; \mathrm{N}-\mathrm{NH}_{4}: 0.05 \mathrm{mg} / \mathrm{l}\right.$; $\mathrm{N}-\mathrm{NO}_{2}: 0.01 \mathrm{mg} / \mathrm{l} ; \mathrm{N}-\mathrm{NO}_{3}: 29.9 \mathrm{mg} / \mathrm{l}$ and total hardness: $133 \mathrm{mg} \mathrm{l}^{-1}$ ) (APHA, 1980). Each tank contained a porous stone aerator and received a continuous flow of water. Mortality rate was recorded at each weighing and crayfish were weighed once a fortnight. Crayfish were fed by automatic feeders 6 times daily. Pellets were manufactured using a meat mincer. During the experiment (spring-summer), E. canadensis plant was reared outdoors in an oxygenated tank. A photoperiod of $12 \mathrm{~h}$ light daily was maintained during the experiments. During the trials, samples of the diet and elodea were collected for proximate analysis (A.O.A.C., 1990) and the gross energy concentration by adiabatic bomb calorimeter.

The experimental data recorded during the growth trial was subjected to one way analysis of variance, GLM procedure, means being compared using the Duncan's multiple range test (SAS 1989).

\section{RESULTS}

The primary focus of the present work was to study the nutritive value of E. canadensis compared to a control diet. The pelleted diet was made of about $75 \%$ of vegetable ingredients (soybean, $17 \%$, lucerne, $15 \%$, and wheat, $36 \%$ ) and $25 \%$ of animal sources (fish meal).

Dietary lipid and protein contents were both roughly $50 \%$ of vegetal and animal origin. Crude protein, ether extract, and gross energy contents were lower in $E$. canadensis

\section{Table I}

\section{Composition of the experimental diet.}

\section{Tableau I}

Composition du régime expérimental.

\begin{tabular}{lc}
\hline Ingredients $\mathbf{( g / k g )}$ & Diet \\
\hline Soybean meal & 170 \\
Lucerne concentrate & 150 \\
Cooked wheat starch & 350 \\
Fish meal & 250 \\
Maize oil & 40 \\
Na alginate & 20 \\
Vit-min mix & 20 \\
\hline
\end{tabular}




\section{Table II}

Proximate analysis of the experimental diet and elodea.

Tableau II

Analyse immédiate du régime expérimental + elodea.

\begin{tabular}{lccc}
\hline & & Diet & Elodea \\
\hline Variables & & & \\
\hline Dry matter & $\%$ & 88.8 & 9.3 \\
Crude protein & \% d.m. & 40.9 & 25.8 \\
Ether extract & \% d.m. & 7.4 & 1.4 \\
Crude fibre & \% d.m. & 13.6 & 14.8 \\
Ash & \% d.m. & 7.4 & 25.8 \\
N-free extract & \% d.m. & 30.7 & 34.2 \\
Gross energy & MJ/kg d.m. & 19.9 & 12.58 \\
P/E & mg/kcal & 68 & 68 \\
\hline
\end{tabular}

compared to the diet. Conversely, ash concentration was higher in E. canadensis. Dietary $\mathrm{P} / \mathrm{E}$ ratio (protein/energy, $\mathrm{mg} / \mathrm{kcal}$ ) was the same for the diet and the plant.

The growth of $A$. astacus fed the pelleted diet (D) and the pelleted diet and elodea $(D+E)$ was higher to that of animals fed elodea (E) alone. Relative growth rate was significantly $(P<0.01)$ higher in $D+E(195 \%)$ and diet $D(143 \%)$ and lower in $E(65 \%)$. The reduced growth that we observed in crayfish fed elodea only can be probably due to the lower dietary lipid level of elodea respect to the standard crayfish requirements. At the end of the experiment, survival rate of $A$. astacus was higher $(\mathrm{P}<0.05)$ for the treatment $D+E(87 \%)$ and $D(81 \%)$ compared to $E(56 \%)$.

\section{Table III}

Initial and final body weight, RGR, SGR, FCR and survival of crayfish, A. astacus fed on the experimental treatments.

Tableau III

Poids initial et final, RGR, SGR, FCR et survie des écrevisses, $A$. astacus nourries dans les conditions expérimentales.

\begin{tabular}{lllll}
\hline Treatments & & & & \\
\hline & D & E & D + E & $\begin{array}{l}\text { Err. Var. } \\
\text { (6 d.f.) }\end{array}$ \\
\hline Initial weight (g) & 0.32 & 0.33 & 0.33 & 0.0020 \\
Final weight (g) & $0.77^{\mathrm{b}}$ & $0.54^{\mathrm{c}}$ & $0.98^{\mathrm{a}}$ & 0.0013 \\
$\mathrm{RGR}^{1}(\%)$ & $143^{\mathrm{a}}$ & $65^{\mathrm{b}}$ & $195^{\mathrm{a}}$ & 978 \\
$\mathrm{SGR}^{2}$ & $1.07^{\mathrm{a}}$ & $0.55^{\mathrm{b}}$ & $1.21^{\mathrm{a}}$ & 0.0264 \\
$\mathrm{FCR}^{3}$ & $1.95^{\mathrm{a}}$ & $7.29^{\mathrm{b}}$ & $1.45^{\mathrm{a}}$ & 2.01 \\
Survival (\%) & $81^{\mathrm{a}}$ & $56^{\mathrm{b}}$ & $87^{\mathrm{a}}$ & 62.7 \\
\hline
\end{tabular}

Means with different superscripts within the same row are significantly different.

1 RGR: Relative growth rate ((final b.w. - initial b.w)/(initial b.w.)).

2 SGR: Specific Growth Rate, ((In[final weight] - In[initial weight]) $\times 100) /$ days.

${ }^{3}$ FCR: Feed Conversion Rate, (feed consumption, g)/(weight gain, g). 


\section{DISCUSSION}

So far, biology, ecology, pathology, distribution, and habitat preferences (NYSTRÖM, 2002) of noble crayfish have been investigated by several authors, while only few researches have been addressed to nutrition (ZANDEE, 1962, 1966 ; ACKEFORS et al., 1989, 1992). Astacus astacus is a selective omnivorous, mainly feeding on aquatic plants, detritus, and benthic invertebrates (SKURDAL and TAUGBØL, 2002). Submerged plants are generally prefered rather than established ones. According to SKURDAL and TAUGBØL (2002), $A$. astacus juveniles eat benthic invertebrates rather than vegetal material.

Chemical composition of water plants is little known. The majority of publications deal with marine algae and freshwater plants are less studied (ROZENTSVET et al., 1995). The lipid content of $E$. canadensis was $140 \mathrm{mg} \mathrm{g}^{-1}$ dry wt. The average lipid concentration of 14 macrophytes of the Middle Volga region ranged between 88 and $178 \mathrm{mg} \mathrm{g}^{-1}$ dry wt (ROZENTSVET et al., 1995). These authors observed a change in the lipid content of macrophytes in relation to the environmental conditions.

One of the most expensive ingredients in feed production is protein. Low cost and alternative protein sources are used for aquaculture feed production to reduce costs. Discrepancies in the optimal protein concentration necessary to yield acceptable growth rate of crayfish are related to protein quality (ACKEFORS et al., 1992). This author (1992) recommended, for optimal growth in juveniles $A$. astacus, a diet containing $35 \%$ proteins, $20-25 \%$ of carbohydrates and no more than $10 \%$ of lipids. Some ingredients, such as squid (Dosidicus gigas), krill (Euphasia sp.), and protein hydrolysates have been reported (CÓRDOVA-MURUETA and GARCIA-CARREŇO, 2002) to possess healthy and nutriceutical properties and have been used as supplements to enhance food properties. In Australia, forage crops have been used to feed crayfish. Green crops such as clover, rye grass, and oats are used, depending on the season and locality (JONES et al., 2002). Presently, most species of crayfish are cultured in extensive and semi-intensive production systems with a low dependence on formulated feeds. Although, considerable variability has been reported in systems where only natural vegetation is used, a generally lower yield was obtained compared with the combined use of pelleted food and vegetation. GEDDES et al. (1993) recorded a $22 \%$ increase in growth of Cherax destructor using lucerne hay in comparison to a $25 \%$ protein pelleted diet and WIERNICKI (1984) found that the assimilation efficiency of $P$. clarkii fed elodea increased, when the plant had been decomposed for several weeks.

\section{CONCLUSION}

Our results suggest that $E$. canadensis can be used in the aquaculture practice as a cheap supplemental food that increases growth and survival in summerling noble crayfish. This conclusion is a confirmation of previous studies (e.g. HESSEN and SKURDAL, 1985) that noble crayfish has the potential of consuming this macrophyte in nature, notwithstanding that guts of samples collected from water bodies invaded for years by the waterweed (e.g. Lake Steinsfjorden, S.E. Norway) did not contain any fresh Elodea remains, but rather detritus and decaying plant matter (HESSEN and SKURDAL, 1985).

\section{REFERENCES}

ABRAHAMSSON S.A.A., 1966. Dynamics of an isolated population and of the crayfish Astacus astacus Linné. Oikos, 17, 96-107.

ACKEFORS H., GYDEMO R. and WESTLIN L., 1989. Growth and survival of juvenile crayfish, Astacus astacus in relation to food and density. In: DE PAUW N., JASPERS E., ACKEFORS H., WILKINS N.) (Eds), Aquaculture. A Biotechnology in Progress, 365-373, European Aquaculture Society, Bredene, Belgium. 
ACKEFORS H., CASTELL J.D., BOSTON L., RATY P. and SVENSSON M., 1992. Standard experimental diets for crustacean nutrition research. II. Growth and survival of juvenile crayfish Astacus astacus (Linné) fed diets containing various amounts of protein, carbohydrate and lipid. Aquaculture, 104, 341-356.

AOAC, 1990. Official Methods of Analysis, $15^{\text {th }}$ edition. Association of Official Analytical Chemists (AOAC). Washington, DC.

APHA, 1980. Standard Methods for the Examination of Water and Wastewater, $15^{\text {th }}$ edition. American Public Health Association. Washington, DC.

BUSCHEMI P.A., 1958. Littoral oxygen depletion produced by a cover of Elodea canadensis. Oikos, 9, 243-245.

CÓRDOVA-MURUETA J.H. and GARCÍA-CARREŇO F.L., 2002. Nutritive value of squid and hydrolysed protein supplement in shrimp feed. Aquaculture, 210, 371-384.

GEDDES C.A. and SMALLRIDGE M., 1993. Survival, growth and yield of the Australian freshwater crayfish Cherax destructor in extensive aquaculture ponds. Aquaculture, 114, 51-70.

EUGELINK A.H., 1998. Phosphorus uptake and active growth of elodea Canadensis michx. and elodea nuttallii (planch.) st. john. Wat. Sci. Tech., 3, 59-65.

HESSEN D.O. and SKURDAL J., 1985. Analysis of the food utilized by the crayfish Astacus astacus in Lake Steinsfjorden, S.E. Norway. Freshwater Crayfish, 6, 187-193.

HESSEN D.O. and SKURDAL J., 1987. Food consumption, turnover rates and assimilation in the noble crayfish (Astacus astacus). Freshwater Crayfish, 7, 309-317.

HORPPILA J., RUUHIJÄRVI J., RASK M., KARPPINEN C., NYBERG K. and OLIN M., 2000. Seasonal changes in the diets and relative abundance of pearch and roach in the littoral and pelagic zones of a large lake. J. Fish Biol., 56, 51-72.

HUTCHINSON G.E., 1975. A treatise on limnology. Vol. 3, Limnological botany. WileyInterscience, New York, 660 pp.

JONES P.L., CHAVEZ J.R. and MITCHELL B.D., 2002. Production of Australian freshwater crayfish in earthen-based systems using pelleted diets and forage crops as food. Aquacult. Int., 10, 157-175.

LODGE D.M., KERSHNER M.W., ALOI J.E. and COVICH A.P., 1994. Effects of an omnivorous crayfish (Orconectes rusticus) on a freshwater littoral web. Ecology, $75,1265-1281$.

LODGE D.M. and LORMAN, J.G., 1987. Reductions in submerged macrophyte biomass and species richness by crayfish Orconectes rusticus. Can. J. Fish. Aquat. Sci., 44, 591-597.

MOMOT W.T., GOWING H. AND JONES P.D., 1978. The dynamics of crayfish and their role in ecosystems. Am. Midl. Nat., 99, 10-35.

NYSTRÖM P., 1999. Ecological impact of introduced and native crayfish on freshwater communities: European perspectives. In: GHERARDI F. and HOLDICH D.M. (Eds) Crayfish in Europe as alien species. How to make the best of a bad situation? 6385, Balkema, Rotterdam.

NYSTRÖM, P., 2002. Ecology. In: HOLDICH D.A. (Ed.), Biology of Freshwater Crayfish, 192-235, Blackwell Science, Oxford.

ROZENTSVET O.A., DEMBITSKY N.M. and ZHUICOVA V.S., 1995. Lipids from macrophytes of the middle Volga. Phytochemistry, 5, 1209-1213. 
SAS, 1989. SAS User's Guide. $4^{\text {th }}$ ed. SAS Institute, Cary, NC, USA.

SCHULTHORPE C.D, 1967. The biology of aquatic vascular plants. Edwards Arnold, London, $610 \mathrm{pp}$.

SKURDAL and TAUGBØL, 2002. Astacus. In: HOLDICH D.A. (Ed.), Biology of Freshwater Crayfish, 467-503, Blackwell Science, Oxford.

ZANDEE D.I., 1962. Lipid metabolism in Astacus astacus (L.). Nature, 195, 814-815.

ZANDEE D.I.,1966. Metabolism in the crayfish Astacus astacus (L.). IV. The fatty acid composition and the biosynthesis of the fatty acids. Archives Internationales de Physiologie et Biochimie, 74, 614-626.

WIERNICKI C., 1984. Assimilation efficiency by Procambarus clarkii fed Elodea and its products of decomposition. Aquaculture, 36, 203-215. 
